\title{
The Role of C-Reactive Protein in the Infections Caused by \\ Parasites(Review)
}

\author{
Entsar Jabbar Saheb $(\mathrm{PhD})^{1}$, Rasha Hussain Kuba $(\mathrm{MSc})^{2}$ and Israa Salim \\ Musa(MSc) $)^{3}$
}

\begin{abstract}
Background: Inflammation causes a rise in the levels of certain proteins; these proteins are identified as acute stage proteins and one of these proteins is $\mathrm{C}$-reactive protein (CRP). CRP composed of 206-amino acid of the short pentraxin family.

Objective: This review assessed CRP as an inflammatory indicator that has an important role in the host's defense against infection and also it is documented the pivotal role of this protein during infections with different parasites.

Conclusion: This review is hypothesizing that CRP levels rise during infections caused by parasites. Other studies revealed that there is no association of soil-transmitted helminths infections with the increasing levels of CRP.

Keywords: C-reactive protein; protozoan parasites; soil-transmitted helminths

Corresponding Author: dr.entsar73@gmail.com

Received: $28^{\text {th }}$ August 2020

Accepted: $17^{\text {th }}$ September 2020

DOI:https://doi.org/10.26505/DJM.19025550828

${ }^{1,2,3}$ Department of Biology-College of Science-University of Baghdad-Iraq

\section{Introduction}

One of the acute-phase inflammatory proteins is C-reactive protein (CRP). Its levels raised during inflammatory conditions for instance rheumatoid arthritis and infections. In addition, CRP is a vital regulator of inflammatory courses [1]. Tillet and Francis, 1930 firstly discovered CRP during their investigation of the sera in patients who had an acute stage of Pneumococcus infection [2]. CRP composes of five identical $23-\mathrm{kDa}$ protomers organized regularly around a central pore. Pentraxins is a term that has been used to describe the family of associated proteins with this structure [3, 4]. CRP is produced in many cells such as lymphocytes, hepatocytes,

adipocytes, smooth muscle cells, liver, macrophages and endothelial cells [1]. CRP concentration in the plasma deviates about $25 \%$ during inflammatory syndromes [5]. With some bacterial infections, the CRP concentration raised up to 1,000-fold [6]. Though, when the motivation eliminated, CRP levels drop within 18-20 hrs [7]. In harmful tissue disorders for example trauma and cancer, CRP plasma concentration rises from about $1 \mu \mathrm{g} / \mathrm{mL}$ to around $500 \mu \mathrm{g} / \mathrm{mL}$ within $72 \mathrm{hrs}$ [8]. Interleukin 6 is a major stimulator of CRP gene expression but it is not sufficient to achieve this alone, while IL1 stimulates its effect $[9,10]$. Human CRP motivates complement 9 and 10 and
\end{abstract}


stimulates tissue-factor production [11, 12]; this proposes that CRP may have proinflammatory effects that contribute to pathogenesis atheroma [13].

CRP has a role in recognizing the foreign pathogens and infected cells through binding with the phosphocholine arm when it exists. It can stimulate the complement system and phagocytic cells via $\mathrm{Fc}$ receptors to remove the cellular debris or apoptotic cells and foreign pathogens. It can also lead to tissue damage in certain cases due to activation of the complement system $[14,15,16]$. CRP has a vital role in protection against infection, removing the injured tissue, and regulation of the inflammatory response. It has both proand anti-inflammatory effects. CRP acts as an opsonin that binds with the polysaccharide residues on bacteria, fungi, and parasites to stimulate the complement and phagocytosis [17].

\section{C-Reactive Protein and Leishmaniasis}

The protozoan Leishmania causes Leishmaniasis disease. The cells of the reticuloendothelial system infect by this parasite [18]. The host immune response against leishmaniasis includes cytokines, antibodies, and acute-phase proteins mainly CRP in normal serum [19]. After tissue damages and infections, CRP significantly increases as a non-specific innate immunity of the host. It is an indicator of inflammatory responses and cytokine motivation [20]. The extensive spreading of phosphocholine in pathogens polysaccharides and in cellular membranes allows CRP to distinguish a variety of pathogens in addition to the damaged membranes and necrotic cells [21]. Musa (2015) revealed that a significant rise in the CRP level $(4.36 \pm 0.23 \mathrm{mg} / \mathrm{l})$ compared with the control group $(2.50 \pm 0.28 \mathrm{mg} / \mathrm{l})$ in patients with visceral leishmaniasis [22]. Another study confirmed that the mean value of CRP before treatment was significantly greater than the control group [23].

\section{C-Reactive Protein and Malaria}

Malaria is a common infection in tropical and subtropical areas [24]. This disease causes high morbidity and mortality in Africa [25]. In malaria, some blood tests, liver function tests, and other indicators have been used. CRP has considered a significant biomarker in malaria especially in the endemic areas where predictable disease signs such as fever might lacking even in people with high parasitic infection [26]. CRP concentration strongly relates with the parasite density in patients' blood [26, 27]. CRP levels is accompanying with malaria $[28,29]$ and other infections [30,31]. It is essentially stimulates the complement pathway, platelet [32], binding to infected erythrocytes and lead to their omitting [33].

In spite of the stated efficacy of traditional CRP examinations in malaria, an additional subtle method is needed for the early observation of malaria complications. Providing a sensitive test for CRP allows detecting low-scale changes in CRP concentration $(1-10 \mathrm{mg} / \mathrm{L})$ in contrasting to the traditional test $(10-1000 \mathrm{mg} / \mathrm{L})$. A study revealed that high-sensitivity CRP levels increase when the parasite density increase in children infected with malaria [34]. Other studies showed that the High-sensitivity CRP levels increased significantly to high parasitemia, this finding proposes that the high-sensitivity CRP values could be a 
possible indicator to diagnose the chronic state of patients with malaria $[35,36]$.

\section{C-Reactive Protein, Entameobiasis and Giardiasis}

Diarrheal diseases are widespread in developed and developing countries [37]. Diarrhea is caused by viruses, bacteria, and parasites [38]. Giardia lamblia and Entamoeba histolytica are the main intestinal parasitic causes for diarrhea [39]. These pathogens cause an important public health [40]. Amoebic dysentery and an amoebic liver abscess are caused by E. histolytica, leading to over a hundred thousand deaths annually [41], while $5-10 \%$ of the population is in danger of giardiasis [42]. Giardiasis and entameobiasis and are often spread by contaminated food and drinking water, or through fecal-oral contact [43].

A study proved that CRP level increased in the chronic presentation of diarrhea caused by $G$. lamblia and E. histolytica, thus CRP can be used as a nonspecific immunological marker for checking the clinical presentation of $G$. lamblia and E. histolytica infection [44]. This activity is more controlled by time and the levels of CRP will be raised after the acute phase of diarrhea caused by G. lamblia and E. histolytica [45,46]. The immune response progress plays a role in the negative relationship between the acute phase of diarrhea caused via $G$. lamblia and $E$. histolytica and the CRP level; the innate immunity distinguish molecules on the $\mathrm{G}$. lamblia and E. histolytica membrane that cause stimulating mucosal related macrophages and CRP level will slightly raise [47]. The site of $G$. lamblia and $E$. histolytica infection in the gut mucosa consider as an additional probable reason for the declining CRP concentration during acute phase of diarrhea; this will protect the parasite from mucosal $\operatorname{IgA}$ and $\operatorname{IgM}$ as a humoral immune response and from phagocytic by macrophages. Another reason for the low levels of CRP during acute phase of diarrhoea related to giardiasis and entameobiasis is the small number of parasites that swallowed [48,45]. Long periods of infection stimulates the activity of hepatocytes to synthesize CRP. On the other hand, attachment of the parasite on the mucosal surface leads to tissue destruction which in turn stimulates the hepatocytes to increase CRP production as the innate response that cooperated with the stimulating phagocytic macrophages and mucosal $\operatorname{IgA}$ response against entameobiasis and giardiasis. Therefore, there is a positive significant increase in the CRP level through the chronic phase of $G$. lamblia and $E$. histolytica related diarrhea $[49,50]$.

\section{C-Reactive Protein and Toxoplasmosis}

Toxoplasmosis is caused by Toxoplasma gondii, an opportunistic protozoan parasite, and produces asymptomatic infection and then remains dormant in the host, however it could reactivate later in life [51]. Oocysts in contaminated food or water or tissue cysts in undercooked meat are the most causes of infection $[52,51]$.

Studies demonstrated that $T$. gondii infection is related to the raising level of CRP $[53,54]$, which detected in a mouse infected with chronic infection of $T$. gondii [55]. Soliman, 2012 establish that 27 samples had positive CRP, this suggests a possible interaction of $T$. gondii with the immune 
response [56].CRP is an inflammatory indicator that plays an important role in infection [57].When comparing CRP with LAT and ELIZA results, 17 samples were found positive in Latex and CRP tests, while 19 samples were found positive in both ELIZA and CRP tests, this demonstrating that $T$. gondii may be associated to the systemic inflammation [58].

\section{C-Reactive Protein and Soil-Transmitted Helminths}

Around a quarter of the world's population is at danger of infection with the soiltransmitted helminths (STH) including Strongyloides stercoralis, Trichuris trichiura Ancylostoma duodenale, Necator americanus, and Ascaris lumbricoides [59]. Many of inflammatory markers were revealed within two study populations (Cuban and Cambodian schoolchildren) with different STH species prevalence and general nutritional status. De Gier et al., 2018 showed that there was no significant relation of STH infections with acute phase proteins. They also detected lower CRP levels in children infected with STH compared with uninfected children [60].

\section{Conclusions}

This review documented that the CRP level increased in correlation with the protozoan parasitic infection and such correlation do not present with soil-transmitted helminths infection.

\section{Recommendations}

Detection the level of CRP can be considered as a nonspecific indicator for checking the clinical manifestation of the protozoan parasitic infection due to the possible correlation between them.

\section{References}

[1]Sproston NR, Ashworth JJ. Role of CReactive Protein at Sites of Inflammation and Infection. Front Immunol. 2018; 9: 754.

[2]Tillett WS, Francis T Jr. Serological reactions in pneumonia with a non-protein somatic fraction of Pneumococcus. J Exp Med. 1930; 52(4):561-71.

[3]Shrive AK, Cheetham GM, Holden D, Myles DA, Turnell WG, Volanakis JE, et al, Three dimensional structure of human Creactive protein. Nat. Struct. Biol. 1996; 3 (4):346-54.

[4]Thompson D, Pepys MB, Wood SP. The physiological structure of human $\mathrm{C}$-reactive protein and its complex with phosphocholine. Structure. 1999; 7 (2):169-77.

[5]Gabay C, Kushner I. Acute-phase proteins and other systemic responses to inflammation. $\mathrm{N}$ Engl J Med. 1999; 340(6):448-54.

[6]Thompson D, Pepys MB, Wood SP. The physiological structure of human $\mathrm{C}$-reactive protein and its complex with phosphocholine. Structure. 1999; 7(2):169-77.

[7]Ridker PM. Clinical application of Creactive protein for cardiovascular disease detection and prevention. Circulation. 2003; 107(3):363-9.

[8]Ciubotaru I, Potempa LA, Wander RC. Production of modified C-reactive protein in U937-derived macrophages. Exp Biol Med (Maywood). 2005; 230(10):762-70.

[9]Szalai AJ, van Ginkel FW, Dalrymple SA, Murray R, McGhee JR, Volanakis JE. Testosterone and IL-6 requirements for human C-reactive protein gene expression in transgenic mice. J Immunol. 1998; 160(11):5294-9. 
[10]Weinhold B, Bader A, Poli V, Rüther U. Interleukin-6 is necessary, but not sufficient, for induction of the humanC -reactive protein gene in vivo. Biochem J. 1997; 325 (3):617-21.

[11]Volanakis JE. Complement activation by C-reactive protein complexes. Ann N Y Acad Sci. 1982; 389: 235-50.

[12]Nakagomi A, Freedman SB, Lau W, Geczy CL. Procoagulant induction on human monocytes by proinflammatory stimulants is amplified by C-reactive protein and interferon- $\gamma$. Circulation. 1996; (8): 4063.

[13]Ramani M, Khechai F, Ollivier V, Ternisien C, Bridey F, de Prost D.. Interleukin-10 and pentoxifylline inhibit Creactive protein-induced tissue factor gene expression in peripheral human blood monocytes. Thromb Haemost. 1995; 73:1082.

[14]Haverkate F, Thompson SG, Pyke SD, Gallimore JR, Pepys MB; European Concerted Action on Thrombosis and Disabilities Angina Pectoris Study Group. Production of C-reactive protein and risk of coronary events in stable and unstable angina. Lancet. 1997; 349(9050): 462-6.

[15] Cleland DA, Eranki AP. Procalcitonin. StatPearls Publishing; 2019.

[16] Jungen MJ, Ter-Meulen BC, Van Osch $\mathrm{T}$, Weinstein HC, Ostelo RWJG. Inflammatory biomarkers in patients with sciatica: a systematic review. BMC Musculoskelet Disord 2019, 9; 20(1):156. [17] Juul-Madsen HR, Viertlböeck B, Härtle S, Smith AL, Göbel TW. Innate immune responses in Avian Immunology. 2nd ed. 2014.
[18]World Health Organization. Control of the Leishmaniases. WHO Technical Report Series; no. 949. Report of a meeting of the WHO Expert Committee on Control of Leishmaniases, Geneva, 2010.

[19]Nahrevanian H, Farahmand M, Aghighi Z, Assmar M, Amirkhani A. Pharmacological evaluation of anti-leishmanial activity by in vivo nitric oxide modulation in Balb/c mice infected with Leishmania major MRHO/IR/75/ER: an Iranian strain of cutaneous leishmaniasis. Exp Parasitol. 2007; 116 (3):233-40.

[20]Nemati S, Nahrevanian H, Haniloo, A, Farahmand M. Investigation on Nitric Oxide and C- Reactive Protein Involvement in AntiLeishmanial Effects of Artemisinin and Glucantim on Cutaneous Leishmaniasis. Adv Stud Biol. 2013; 5(1):27 36.

[21]Volanakis, JE. Human C-reactive protein: expression, structure, and function. Mol Immunol. 2001; 38(2-3):189-97.

[22]Musa SI. Study of Some Serological Tests on Patients with Visceral Leishmaniasis. IASJ. 2015;56: 1C: 645--8. [23]Singh UK, Patwari AK, Sinha RK, Kumar R. Prognostic value of serum Creactive protein in kala-azar. $\mathrm{J}$ Trop Pediatr. 1999; 45(4):226-8.

[24]Caraballo, H, King K. Emergency department management of mosquito-borne illness: malaria, dengue, and West Nile virus. Emerg Med Pract. 2014; 16(5): 1-23.

[25]WHO. World malaria report, Geneva: WHO; 2015.

[26] Hurt N, Smith T, Tanner M, Mwankusye S, Bordmann G, Weiss NA, et al. Evaluation of C-reactive protein and haptoglobin as malaria episode markers in an area of high 
transmission in Africa. Trans R Soc Trop Med Hyg. 1994; 88( 2):182-6.

[27]Hurt N, Smith T, Teuscher T, Tanner M. Do high levels of $\mathrm{C}$-reactive protein in Tanzanian children indicate malaria morbidity. Clin Diagn Lab Immunol. 1994; 1(4): 437-44.

[28]Paul R, Sinha PK, Bhattacharya R, Banerjee AK, Raychaudhuri P, Mondal, J. Study of $\mathrm{C}$ reactive protein as a prognostic marker in malaria from Eastern India. Adv Biomed Res. 2012; 1(1): 41.

[29]Gillespie SH, Dow C, Raynes JG, Behrens RH, Chiodini PL, McAdam, KP. Measurement of acute phase proteins for assessing severity of Plasmodium falciparum malaria. J Clin Pathol. 1991; 44(3): 228-31. [30]Díez-Padrisa, N, Bassat Q, Machevo S, Quintó L, Morais L, Nhampossa T, et al. Procalcitonin and C-reactive protein for invasive bacterial pneumonia diagnosis among children in Mozambique, a malariaendemic area. PLoS One. 2010; 5(10):e13226.

[31]West BA,Peterside O, Ugwu RO, Eneh, AU . Prospective evaluation of the usefulness of C-reactive protein in the diagnosis of neonatal sepsis in a sub-Saharan African region. Antimicrob Resist Infect Control. 2012; 1(1) : 22 .

[32]Dongmo, F, Ngane R, Gouado I. Predictors of childhood severe malaria in a densely populated area: Douala, Cameroon. Afr. J. Biotechnol. 2011; 10: 6319-24.

[33]Ansar W, Bandyopadhyay SM, Chowdhury S, Habib SH, Mandal C. Role of C-reactive protein in complement-mediated hemolysis in Malaria. Glycoconj J. 2006; 23 (34):233-40.
[34]Addai-Mensah O, Annani-Akollor ME, Fondjo LA, Anto EO, Gyamfi D, Sallah L, Agama D, Djabatey R, Owiredu, E.. HighSensitivity C-Reactive Protein: A Potential Ancillary Biomarker. Disease Markers. 2019; (5):7.

[35]Lyke KE, Burges, R, Cissoko Y, Sangare L, Dao M, Diarra I et al. Serum levels of the proinflammatory cytokines interleukin-1 beta (IL-1beta), IL-6, IL-8, IL-10, tumor necrosis factor alpha, and IL-12(p70) in Malian children with severe Plasmodium falciparum malaria and matched uncomplicated malaria or healthy controls. Infect Immun. 2004; 72(10): 5630-7.

[36]Clark IA, Alleva LM, Budd AC, Cowden, WB. Understanding the role of inflammatory cytokines in malaria and related diseases. Travel Med Infect Dis. 2008; 6 (1-2): 67-81.

[37]Guerrant R.L, Hughes JM, Lima NL, Crane J. Diarrhea in developed and developing countries: magnitude, special settings, and etiologies. Rev. Infect. Dis. 1990; 12 S41eS50.

[38]Tinuade, O, John O, Saheed, O, Oyeku O, Fidelis, N, Olabisi, D. Parasitic etiology of childhood diarrhea. Indian J. Pediatr. 2006; 73: 1081e1084.

[39]Bray R.S. and Harris, W.G. The epidemiology of infection with Entamoeba histolytica in the Gambia, West Africa. Trans. R. Soc. Trop. Med. Hyg. 1977; 71: $401 \mathrm{e} 407$.

[40]Haque R, Human intestinal parasites. J. Health Popul Nutr. 2007; 25: 387e391.

[41]Fletcher S. M, Stark D, Harkness J. and Ellis J. Enteric protozoa in the developed 
world: a public health perspective. Clin. Microbiol. Rev. 2012; 25: 420e449.

[42]Walsh J.A. Problems in recognition and diagnosis of amebiasis: estimation of the global magnitude of morbidity and mortality. Rev. Infect. Dis. 1986; 8: 228e238.

[43]Stanley SL. Amoebiasis. Lancet. 2003; 361(9362):1025-34.

[44] Al-Ezzy AI, Abood WN, Hussein, RA. $\mathrm{C}$ - reactive protein as an immunopathological prognostic marker for Giardia lamblia and Entamoeba histolytica associated diarrhea among children of Baghdad Governorate. IJASR. 2015; 1(01): 33-7.

[45]Mehlhorn, H. Encyclopedic Reference of Parasitology, Biology, Structure, Function. Springer Ltd; 2001.

[46]AL-Ezzy, A.I.A. and Abood, W.N. Immuno-Microbiological Diagnosis of CoInfections with Rota Virus, Giardia lamblia, Entamoeba histolytica and Salmonella enterica as a Possible pathological strategy for acute diarrheal among Iraqi Children. Int J Adv Res (Indore). 2013; 1: 216-24.

[47]Gorczynski RaS, J. Clinical Immunology. Land bioscience Ltd. 1999.

[48] Mahon CR and Flaws ML. Host-Parasite Interaction. 2014. 23 pp.

[49]Safi S. Acute Phase Proteins-Analysis, Clinical Applications and Potentials, Inflammatory Diseases- Immunopathology. Clinical and Pharmacological Bases. InTech Open press. 2012.

[50]Macy EM, Hayes TE, Tracy RP Variability in the measurement of C-reactive protein in healthy subjects: implications for reference intervals and epidemiological applications. Clin. Chem. 1997; 43(1):52-8. [51]Saadatnia G, Golkar M.A review on human toxoplasmosis. Scand J Infect Dis. 2012; 4 4(11):805-14.

[52]Montoya.JG,Liesenfeld.O.Toxoplasmosi s.Lancet.2004;363(9425):1965-76.

[53]Birgisdóttir A, Asbjörnsdottir H, Cook E, Gislason D, Jansson C, Olafsson I, et al. Seroprevalence of Toxoplasma gondii in Sweden, Estonia and Iceland. Scand J Infect Dis. 2006; 38(8):625-31.

[54]Hinze-Selch D, Däubener W, Eggert L, Erdag S, Stoltenberg R, Wilms S. A controlled prospective study of Toxoplasma gondii infection in individuals with schizophrenia: beyond seroprevalence. Schizophr Bull. 2007; 33(3):782-8.

[55]Tomasik J, Schultz TL,Kluge W, YolkenRH, Bahn S, Carruthers VB. Shared immune and repair markers during experimental Toxoplasma chronic brain infection and schizophrenia. Schizophr Bull. 2016; 42(2):386-95.

[56]Soliman,N.M.Evaluation

of

Toxoplasmosis Infection by Using Latex and Eliza Tests and it's Relation with C-reactive Protein. DJPS. 2012; 8(1).

[57]Black S, Kushner I, Samols DC reactive Protein. J Biol Chem. 2004; 279(47):4848790.

[58]Alda B, Hulda A, Elisabeth C, Rian J.Seroprevalence of Toxoplasma gondii in Sweden, Estonia and Icland. Scad [Addiss DG]. J. Infect. Dis. 2006; 38: 625-31.

[59] Jourdan PM, Lamberton PH, Fenwick, Addiss DG Soil-transmitted helminth infections. Lancet. 2018; 391(10117): 25265.

[60]De Gier, B.,; Pita-Rodríguez GM, Campos-Ponce M, van. de Bor M, Chamnan C, Junco-Díaz $\mathrm{R}$ et al. Soil-transmitted 
helminth infections and intestinal and systemic inflammation in schoolchildren.

Acta Trop. 2018; 182: 124-7. 